\title{
Vesical urothelium proliferation in spinal cord injured persons: an immunohistochemical study of PCNA and MIB.1 labelling
}

\author{
D van Velzen ${ }^{2}$, KR Krishnan ${ }^{1}, \mathrm{KF}$ Parsons $^{1}, \mathrm{BM} \mathrm{Soni}^{1}, \mathrm{CV}$ Howard $^{2}$, MH Fraser ${ }^{1}$ and S Vaidyanathan ${ }^{1}$ \\ ${ }^{1}$ Regional Spinal Injury Centre, District General Hospital, Town Lane, Kew, Southport, Merseyside, PR8 6PN; \\ ${ }^{2}$ Department of Fetal and Infant Pathology, University of Liverpool, Liverpool, UK
}

\begin{abstract}
Urinary tract infection occurs more commonly, is more virulent and proves more difficult to eradicate in spinal cord injury persons than in the neurologically intact. In order to find out the peculiarities of the neuropathic bladder which make it vulnerable to recurrent cystitis, we studied the proliferation status of the urothelium in spinal cord injured persons. Eleven consecutive, unselected male spinal cord injury patients (aged 18-73 years) were included in the study. Those with, or undergoing treatment for acute urinary tract infection were excluded. All patients underwent cystoscopy and cold cup bladder biopsy from the trigone and bladder dome. Immunocytochemical analysis was performed using defined, commercially available antibodies for PCNA (PCNA 10, DAKO) and MIB-1 (raised against recombinant DNA defined segment of $\mathrm{Ki}-67$ antigen DAKO) streptavidin/biotin and alkaline phosphatase immunocytochemistry (for MIB-1 with microwave-enhanced antigen retrieval) were used to demonstrate the presence of cell cycling-associated nuclear proteins. Foci of lymphocytic aggregations present in the sections served as in-section controls for antigen preservation. Ten patients showed labelling of $20-70 \%$ of cells for PCNA in basal cell layers of dome lining. Higher urothelial layers showed a variable, but generally reduced degree of labelling. Of these 10 patients, three showed complete absence of MIB-1 activity in the basal and other layers of dome urothelium and two demonstrated only a very occasional positive nucleus. MIB-1 labelling was $<5 \%$ in four others and it was between $5 \%$ and $10 \%$ in one. In the trigone, PCNA labelling was $20-70 \%$ in nine and $<20 \%$ in two others. Of the former nine, MIB-1 labelling was $<5 \%$ in five; patchy staining was observed in one; and MIB-1 labelling was completely absent in three. The absence of proliferation was not correlated with urothelium thickness. Absence of MIB-1 expression, with maintained PCNA expression suggests effective arrest due to external factors. The dissociation between MIB-1 and PCNA expression may be an effect of defective innervation of the bladder in spinal cord injured persons. Absence of proliferation would be expected to alter the relative maturity of bladder lining cells. Alterations in the surface structure of urothelium may contribute to changes in the expression of cell adhesion molecules relevant to bacterial adherence and colonisation.
\end{abstract}

Keywords: Spinal cord injury; urinary bladder; PCNA; MIB-1; urinary tract infection

\section{Introduction}

Urinary tract infection and cystitis occur frequently in spinal cord injured patients. Three to four episodes of cystitis in a year, which is not uncommon in some paraplegics and tetraplegics, result in considerable morbidity in terms of (1) feeling unwell and inability to participate in social events for 3-4 weeks per year; (2) economic loss - cost of drugs and loss of earnings if a person is employed; (3) additional nursing requirements during the period(s) of illness; (4) hospitalisation costs for acute urinary tract infection or for autonomic dysreflexia associated with cystitis and (5) progressive renal damage with each episode of pyelonephritis.
In our clinical practice, we observed that the commonest medical problems for those who are paraplegic or tetraplegic (after they have recovered from the acute effects of trauma) were those related to the urinary tract, eg a blocked catheter or cystitis. Along with cystitis, some tetraplegic patients develop autonomic dysreflexia which requires urgent medical attention.

Quite a few paraplegic and tetraplegic individuals develop haematuria. In fact, we noticed that the commonest aetiological factor for haematuria in such people is cystitis. It is possible that recurrent exudative cystitis in the neuropathic bladder may have deleterious long-term sequelae, as white cells in an exudate produce powerful oxidants-superoxide, peroxide, and

Correspondence: Dr S Vaidyanathan 
hydroxyl radicals and singlet oxygen - that can damage the DNA of normal cells and thereby cause mutations that are presumably carcinogenic. This concept of malignant transformation produced by human neutrophils proposed by Weitzman and associates ${ }^{1}$ is strongly supported by recent studies. ${ }^{2}$ Thus it becomes imperative to decrease the incidence of cystitis in spinal cord injured patients in order to reduce the chances of neoplastic changes occurring in the neuropathic bladder over a period of decades.

There are secondary problems associated with cystitis. Transient increased spasms are observed during the acute urinary infection. Urinary leakage may occur between catheterisations in persons practising intermittent catheterisation and bypassing of the catheter in those with indwelling urethral catheter drainage. The latter may contribute to the development of pressure sores when the person lies on urine-soaked sheets.

Furthermore, repeated episodes of urinary tract infection may have a devastating consequence on the fertility potential of a young male paraplegic or tetraplegic person who wishes to father a child. Epididymitis may cause obstruction to the seminiferous tubules; orchitis impairs spermatogenesis and rarely may require orchidectomy in those in whom orchitis progresses to a testicular abscess; prostatitis impairs the quality of seminal fluid and leads to impaired mobility of sperm and necrospermia. In female paraplegic and tetraplegic patients, recurrent urinary infection seriously compromises the chances of initiating or sustaining a pregnancy.

During experimental cystitis in mice with Escherichia coli, it was observed that inoculated $E$. coli did not adhere to the intact bladder epithelium. ${ }^{3}$ However, when the mouse bladder was treated with trypsin, superficial cells were exfoliated, and the inoculated type 1 fimbriated $E$. coli adhered to the exposed intermediate cells and caused cystitis. The non-fimbriated $E$. coli showing no adherence to the superficial cells or intermediate cells failed to cause cystitis. This study demonstrated that the type 1 fimbriated $E$. coli play a role in causing cystitis, and the bladder superficial cells play a role in resisting the adherence of $E$. coli, and that the removal of superficial urothelial cells is essential for the adhesion and colonisation of type 1 fimbriated $E$. coli onto the bladder urothelium in vivo. This observation may have significant relevance to the occurrence of cystitis in spinal cord injury patients.

Neural damage to the urinary bladder occurs with the onset of spinal cord trauma. Followed by medical interventions such as indwelling urethral catheter drainage or suprapubic urinary drainage during the acute phase, the final status of the urothelium may well be determined by the functional abnormality of the suprasacral neuropathic bladder or by episodes of urinary retention with distension during trials of micturition in those with an acontractile bladder. During this period, asymptomatic bacteriuria, bacterial colonisation of urinary bladder lining and episodes of acute urinary infection will further modulate the functional quality of the bladder lining. In addition to potential repeated trauma, any such changes of the normal architecture observed in the bladder urothelium of spinal cord injured persons may be the consequence of bladder denervation/decentralization or may represent the sequelae of cystitis per se and may predispose to recurrence of cystitis.

These factors are all ongoing events and occur with varying frequency and severity in individual patients over a period of months and years after spinal cord injury. Considerable variability of the mucosal vulnerability therefore may exist between patients or within one patient in time.

For clinical research purposes, it is difficult to recruit a homogenous group of, for example, male tetraplegic patients within strict age limits and at a consistent time point after the initial injury. To stratify based on treatment and on clinical episodes of infection presents more difficulty when further correction for trauma due to indwelling urethral catheter drainage, or bladder overdistension, is attempted. Finally,'suppressive antibacterial therapy may vary greatly in individual patients, and when comparing one with another with the same neurological lesion.

However, all patients may share a single final common pathway of urothelial deficiency. Abnormal proliferation/regeneration of urothelium may result in abnormalities of the superficial lining cells which may have effects on the ability of fimbriated $E$. coli to achieve adherence. Proliferation assessment of epithelium, other than by simple recognition of layer thickness, is difficult in humans by the unacceptability of in-vivo labelling of proliferating cells by radioactive thymidine. The alternative of bromo-deoxyuridine incorporation is similarly not feasible. Carrying out such studies by short duration in-vivo labelling is subject to unpredictable effects of the culture procedure per se on the highly energy dependent process of DNA replication. Recently monoclonal antibodies, suitable for application to formaldehyde fixed, paraffin embedded tissue, directed against cell cycling associated nuclear antigens have become available. These include antibodies directed against proliferating cell nuclear antigen (PCNA-10) and Ki 67 antigen (using the monoclonal antibodies suitable for detection of the recombinant DNA based MIB-1 fragment of the Ki 67 antigen) has offered a useful alternative. ${ }^{4}$ Most recently, the application of messenger RNA in situ hybridisation for DNA histone protein has offered an additional method to allow for quality control on the two main markers currently in research and clinical use.

At present little information exists with respect to the application of these techniques to the assessment of the bladder urothelium. As such it was considered opportune to carry our a prospective limited study, in which all spinal cord injured patients who underwent a diagnostic cystoscopy for a clinical indication other than infection were to be included. This open study design included the provision of full informed consent by the patient for bladder biopsy as he/she was undergoing a cystoscopic procedure for the clinical condition for which he/she was being hospitalised. 


\section{Aim of the study}

We decided to investigate the quality and proliferative status of the bladder urothelium in spinal cord injured persons. As cystitis is the commonest entity amongst the various manifestations of acute urinary tract infection in paraplegic and tetraplegic people, we decided to investigate the biopsy material independent of the presence of acute inflammation. Biopsies were assessed for suitability based on the presence of surface lining cells (umbrella cells) in the final sections.

\section{Materials and methods}

\section{Study population}

Eleven consecutive, unselected spinal cord injured patients were included in the study. Written, informed consent for bladder biopsy was obtained from them before cystoscopy for some other elective procedure. Clinical details are presented in Table 1.

\section{Biopsies}

Cold cup biopsies were taken from the fundus and the trigone of the urinary bladder. If there was bleeding from the biopsy site, it was fulgurated with diathermy. All participants underwent the procedure without any intraoperative or postoperative complication. Performance of bladder biopsy did not result in any additional period of hospitalisation; the patient who underwent $\mathrm{JJ}$ stenting and bladder biopsy was discharged the same evening.
Tissue processing, histology

Bladder biopsies were fixed by immediate immersion in $0.1 \mathrm{M}$, phosphate buffered, $4 \%$ formaldehyde, $\mathrm{pH} 7.4$ for a minimum of 6 and a maximum of $12 \mathrm{~h}$. After dehydration, specimens were routinely processed to paraplast using vacuum processing and a maximum temperature of $53^{\circ} \mathrm{C}$. Five micron sections were cut and mounted routinely for either haematoxylin and eosin staining or immunocytochemical analysis.

\section{Pathological analysis}

Bladder biopsies were assessed blind and randomised and graded for the presence, extent and type of inflammatory reaction. The thickness (in layers of nuclei) and evenness of the urothelium was recorded as were the presence or absence of superficial lining ('umbrella') cells. The presence or loss of a normal architecture of maturation, with the appearance of giant cells, was similarly recorded.

\section{Immunocytochemistry}

Ki-67 antigen was detected using the MIB-1 staining procedure with antigen retrieval in a microwave. For PCNA staining, the primary antibody (PCNA 10, DAKO Product number 0505) was used in a 1:300 dilution and the MIB-1/Ki-67 equivalent antigen antibody (the Binding Site, Product number 0505) was used in a 1:200 dilution. Routine haematoxylin counterstaining was used for identification of negative nuclei.

Table 1 Clinical details of the patients in whom bladder biopsy was performed

\begin{tabular}{|c|c|c|c|c|c|c|c|}
\hline Patient & Sex & $D o b$ & $\begin{array}{l}\text { Date of } \\
\text { onset of } \\
\text { SCI }\end{array}$ & $\begin{array}{l}\text { Level of } \\
\text { paralysis }\end{array}$ & $\begin{array}{l}\text { Present method of } \\
\text { urinary drainage }\end{array}$ & $\begin{array}{l}\text { Indication for } \\
\text { cystoscopy }\end{array}$ & $\begin{array}{l}\text { Past urological } \\
\text { operations }\end{array}$ \\
\hline 1 & $\mathbf{M}$ & 06.02 .21 & 15.12 .51 & $\mathrm{~T} 12$ & $\begin{array}{l}\text { Intermittent } \\
\text { catheterisation with } \\
\text { penile condom drainage }\end{array}$ & $\begin{array}{l}\text { Urethral calculus } \\
\text { Difficulty in inserting a } \\
\text { catheter per urethra }\end{array}$ & \\
\hline 2 & $\mathbf{M}$ & 10.04 .44 & 17.08 .90 & $\mathrm{~T} 7$ & $\begin{array}{l}\text { Intermittent } \\
\text { catheterisation }\end{array}$ & History of haematuria & \\
\hline 3 & $\mathbf{M}$ & 06.06 .73 & 29.07 .93 & $\mathrm{C} 4 / 5$ & $\begin{array}{l}\text { Indwelling urethral } \\
\text { catheter }\end{array}$ & Vesical calculus & $\begin{array}{l}\text { Electrohydraulic } \\
\text { lithotripsy of vesical } \\
\text { calculus }\end{array}$ \\
\hline 4 & M & 24.06 .60 & 22.08 .84 & $\mathrm{C} 5 / 6$ & Condom drainage & Haematuria & \\
\hline 5 & $\mathbf{M}$ & 11.09 .34 & 29.04 .67 & T10 & Condom drainage & Haematuria & \\
\hline 6 & $\mathbf{M}$ & 23.12 .39 & 03.11 .93 & $\mathrm{C} 5$ & $\begin{array}{l}\text { Indwelling urethral } \\
\text { catheter drainage }\end{array}$ & $\begin{array}{l}\text { External urethral } \\
\text { sphincterotomy }\end{array}$ & \\
\hline 7 & $\mathbf{M}$ & 21.09 .71 & 18.12 .91 & $\mathrm{C} 5$ & Condom drainage & $\begin{array}{l}\text { JJ stenting prior to } \\
\text { ESWL of renal calculus }\end{array}$ & \\
\hline 8 & $\mathbf{M}$ & 30.09 .31 & 24.01 .94 & $\mathrm{C} 5$ & $\begin{array}{l}\text { Indwelling urethral } \\
\text { catheter drainage }\end{array}$ & $\begin{array}{l}\text { TUR of prostate and } \\
\text { external urethral } \\
\text { sphincterotomy }\end{array}$ & \\
\hline 9 & $\mathbf{M}$ & 23.02 .58 & 29.11 .80 & $\mathrm{C} 5$ & $\begin{array}{l}\text { Sacral anterior root } \\
\text { stimulator with condom } \\
\text { drainage }\end{array}$ & $\begin{array}{l}\text { Prostatic urethral } \\
\text { calculus causing } \\
\text { obstruction to urine flow }\end{array}$ & $\begin{array}{l}\text { Implantation of sacral } \\
\text { anterior root stimulator }\end{array}$ \\
\hline 10 & $\mathbf{M}$ & 05.06 .76 & Since birth & T6 & Condom drainage & Urethral false passage & \\
\hline 11 & $\mathbf{M}$ & 13.06 .38 & 06.02 .61 & $\mathrm{~T} 8$ & Condom drainage & Haematuria & \\
\hline
\end{tabular}




\section{Quantitation}

The labelling index for each antigen was assessed semiquantitatively and separately for basal, suprabasal, mid-height and the most superficial layers of urothelium by random sampling of areas in the biopsy. Foci of lymphocytic aggregations present in the sections served as in-section controls for antigen preservation.

\section{Results}

\section{Histopathology}

The histopathological and immunocytochemical findings are summarised in Table 2. Bladder dome biopsy revealed early squamous metaplasia and focal adenomatoid metaplasia in a 55-year-old tetraplegic (Figure 1). Haemorrhagic cystitis was observed in two others who presented with haematuria. Follicular cystitis was noted in the dome as well as trigone biopsy in two cases (Figure 2). Non-specific chronic/active inflammatory changes were observed in the rest.

\section{Immunocytochemical findings}

PCNA labelling in the bladder dome biopsy varied between $20 \%$ and $70 \%$ in the basal layers in 10 of the 11 cases. Of these 10 , three showed complete absence

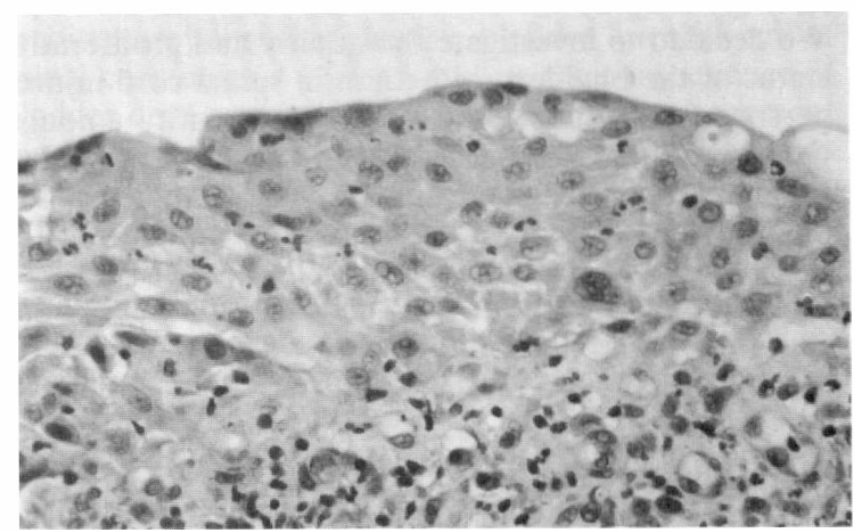

Figure 1 Microphotograph of urinary bladder dome biopsy in a 55-year-old tetraplegic patient. Note squamous metaplasia (solid arrow) with loss of normal maturation and umbrella cells. Five micron paraffin section, haematoxylin and eosin stain, microscopic magnification $50 \times$

of MIB-1 labelling; MIB-1 labelling was $<5 \%$ in four others; two demonstrated only a very occasional positive urothelial cell; and the labelling was between $5 \%$ and $10 \%$ in one. In the trigone biopsy, PCNA labelling was between $20 \%$ and $70 \%$ in nine cases; and

Table 2 Histopathological and immunocytochemical findings of bladder biopsies

\begin{tabular}{|c|c|c|c|c|c|}
\hline Patient & & $\begin{array}{l}\text { Epithelial thickness } \\
\text { No of cell layers }\end{array}$ & Histology & $\begin{array}{l}\text { PCNA } \\
\text { Labelling }\end{array}$ & MIB-1 Labelling \\
\hline \multirow[t]{2}{*}{1} & Dome & $4-5$ & Non-specific active cystitis & $30-40 \%$ & $<2 \%$ \\
\hline & Trigone & & Highly active non-specific cystitis & $70-80 \%$ & $<2 \%$ \\
\hline \multirow[t]{2}{*}{2} & Dome & $9-10$ & $\begin{array}{l}\text { Mild non-specific chronic inflammatory } \\
\text { change }\end{array}$ & $40 \%$ & Devoid of positivity \\
\hline & Trigone & $6-12$ & $\begin{array}{l}\text { Moderately active chronic } \\
\text { inflammatory infiltration }\end{array}$ & $50-60 \%$ & $<5 \%$ \\
\hline \multirow[t]{2}{*}{3} & Dome & $6-7$ & Mild chronic inflammatory change & $50-60 \%$ & $<5 \%$ \\
\hline & Trigone & $9-10$ & $\begin{array}{l}\text { Severe active chronic inflammatory } \\
\text { change }\end{array}$ & $70-90 \%$ & Patchy staining \\
\hline \multirow[t]{2}{*}{9} & Dome & $7-8$ & $\begin{array}{l}\text { Chronic non-specific inflammatory } \\
\text { change }\end{array}$ & $20-70 \%$ & $\begin{array}{l}\text { Only a very occasional } \\
\text { urothelial cell is positive }\end{array}$ \\
\hline & Trigone & $5-10$ & $\begin{array}{l}\text { Moderately active chronic } \\
\text { inflammatory infiltrate }\end{array}$ & $<50 \%$ & $2-5 \%$ \\
\hline \multirow[t]{2}{*}{4} & Dome & $5-6$ & Haemorrhagic cystitis & $50-60 \%$ & $<1 \%$ \\
\hline & Trigone & $7-8$ & Moderately active chronic cystitis & $40-50 \%$ & $<5 \%$ \\
\hline \multirow[t]{2}{*}{5} & Dome & & Haemorrhagic cystitis & $30-60 \%$ & Completely absent \\
\hline & Trigone & & Moderately active chronic cystitis & $5-10 \%$ & No positivity \\
\hline \multirow[t]{2}{*}{6} & Dome & 8 & $\begin{array}{l}\text { Early squamous metaplasia, focal } \\
\text { adenomatoid metaplasia }\end{array}$ & $20-30 \%$ & $<1 \%$ \\
\hline & Trigone & & Active, chronic inflammatory change & $<20 \%$ & $<5 \%$ \\
\hline \multirow[t]{2}{*}{7} & Dome & & Mild chronic cystitis & $<10 \%$ & No positivity \\
\hline & Trigone & & Chronic cystitis & $50 \%$ & No positivity \\
\hline \multirow[t]{2}{*}{8} & Dome & $3-5$ & Follicular cystitis & $30-70 \%$ & $5-10 \%$ \\
\hline & Trigone & $7-8$ & Follicular cystitis & $<50 \%$ & $<10 \%$ \\
\hline \multirow[t]{2}{*}{11} & Dome & $4-5$ & Follicular cystitis & $20-40 \%$ & Negative \\
\hline & Trigone & $5-8$ & Follicular cystitis & $20 \%$ & No activity \\
\hline \multirow[t]{2}{*}{10} & Dome & $5-7$ & Intestinal metaplasia & $20-40 \%$ & $\begin{array}{l}\text { An occasional } \\
\text { positive nucleus seen }\end{array}$ \\
\hline & Trigone & & $\begin{array}{l}\text { Non-specific inflammatory change. } \\
\text { Limited focal atypia }\end{array}$ & $20-50 \%$ & $\begin{array}{l}\text { Virtually devoid of } \\
\text { any positivity }\end{array}$ \\
\hline
\end{tabular}




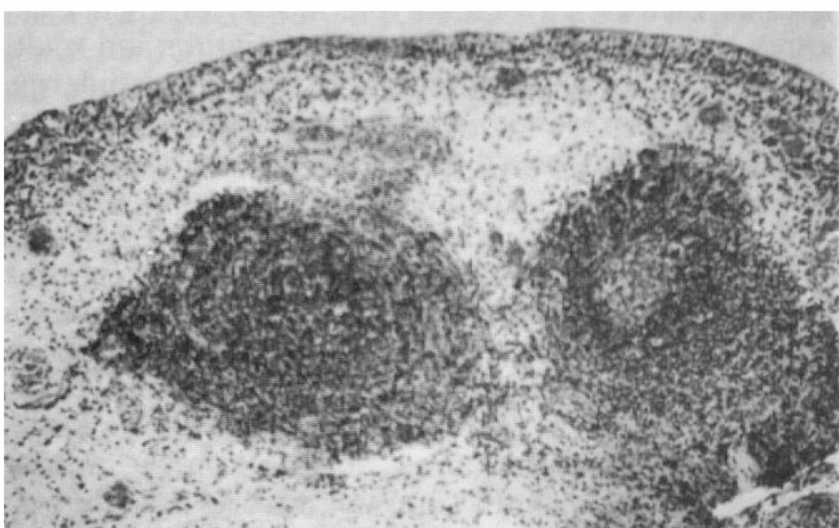

Figure 2 Microphotograph of urinary bladder trigone biopsy in a 56-year-old paraplegic patient. Note generally intact urothelial lining with submucosal follicular aggregates of lymphoid cells showing development of follicle centre reactions (solid arrow). Five micron paraffin section, haematoxylin and eosin stain, microscopic magnification $50 \times$

$<20 \%$ in two. Of the former nine cases, MIB-1 labelling was $<5 \%$ in five; patchy staining was observed in one; and MIB-1 labelling was completely absent in three.

The dome biopsy in a paraplegic patient who presented with recurrent cystitis and haematuria revealed PCNA labelling of 30-60\% (Figure 3). MIB-1 labelling was virtually absent in that biopsy specimen (Figure $4 \mathrm{a}$ and Figure $4 \mathrm{~b}$ ). PCNA labelling of $50 \%$ was noted in the trigone biopsy of a tetraplegic who had a renal calculus (Figure 5). No positivity was found with immunohistochemical staining for MIB-1 in the presence of adequate in-section controls (lymphoid aggregates).

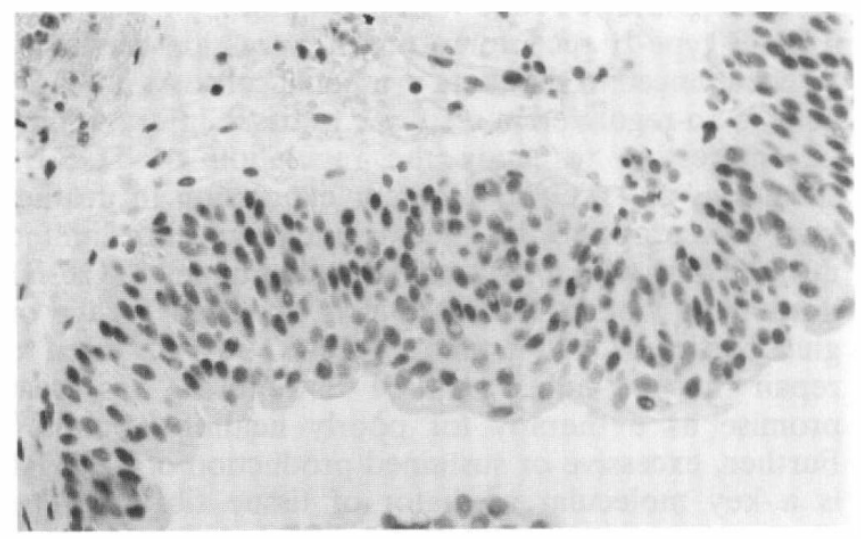

Figure 3 Microphotograph of urinary bladder dome biopsy in a 60 -year-old paraplegic patient stained for PCNA expression of urothelial cells. Note the dark nuclear staining identifying expression of cell cycle associated nuclear antigen. Note concentration of positivity in more basal layers and overall labelling of between $30 \%$ and $60 \%$ of nuclei consistent with normal cell proliferation. Five micron paraffin section, routine PCNA immunolabelling (see materials and methods), microscopic magnification $50 \times$ $\mathbf{a}$

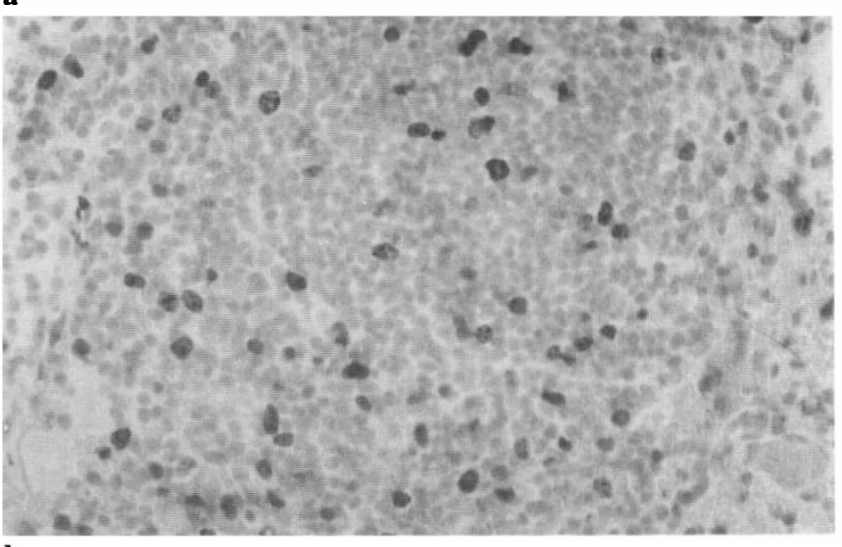

b

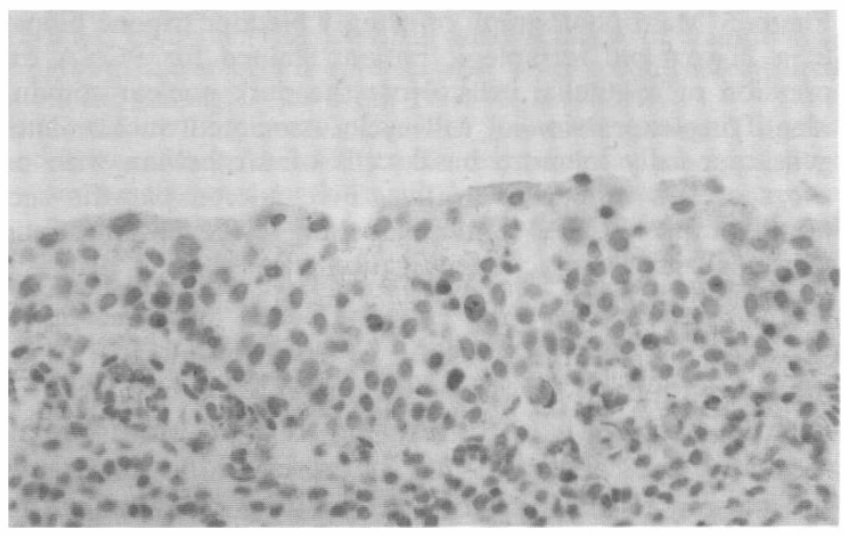

Figure 4 Microphotographs of urinary bladder dome biopsy in the same patient as in Figure 3 stained for MIB-1 expression of urothelial cells. Note the dark nuclear staining identifying expression of cell cycle associated nuclear antigens in proliferating cells of follicle centre (a) with virtual absent expression in nuclei of urothelium (b) consistent with arrest of proliferation. Five micron paraffin section, routine MIB-1 immunolabelling with antigen retrieval (see materials and methods), microscopic magnification $50 \times$

\section{Discussion}

In this preliminary study on spinal cord injured persons, urothelial proliferation arrest was frequently observed. As the proliferation rate of tissues is inversely related to the degree of maturation, it is reasonable to expect that cells 'trapped' in the early S-phase of the cell cycle will have a different maturation status and thus biological characteristics of the cell surface. Especially when exposed to infected urine, this will hypothetically result in differences in properties important to bacterial adherence viz. differentiationdependent expression of cell-cell adhesion molecules, such as members of the selectin class and $\mathrm{IgG}$ superfamily. Alterations of these molecules that support interactions between cells may then predispose to the development of pathological colonisation of urothelium preceding tissue invasion and finally infection. Suboptimal urothelial proliferation in the neuropathic bladder of spinal cord injury persons thus may produce an environment favourable to bacterial adhesion and 


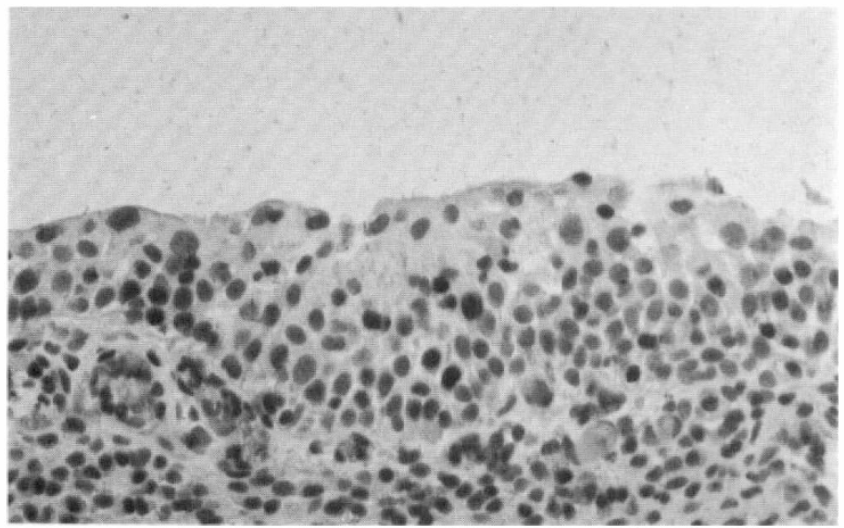

Figure 5 Microphotograph of urinary bladder trigone biopsy in a 21-year-old tetraplegic patient stained for PCNA expression of urothelial cells. Note the dark nuclear staining identifying expression of cell cycle associated nuclear antigens especially in more basal cells of urothelium with on average $50 \%$ of nuclei positive. Five micron paraffin section, routine PCNA immunolabelling (see materials and methods), microscopic magnification $50 \times$

subsequent bacterial invasion of urinary bladder. If so, then one method for prevention of cystitis would be to normalise urothelial proliferation to the optimum level reducing the potential for bacterial adherence and subsequent tissue invasion. Presently, the approach to cystitis consists mainly of the use of prophylactic antibiotics, the value of which has been questioned. ${ }^{5}$ Repeated antibiotic therapy sometimes produces systemic side effects; it may lead to development of resistant strains and antibiotic therapy is expensive. Recently, it has been shown that bacterial biofilms exist which are adherent to the bladder lining cells of spinal cord injury patients ${ }^{6}$ and that these biofilms correlate with a significant loss by cell death of these superficial epithelial cells? Adherent bacteria were found on bladder cells from 66 of the 69 samples (96\%) examined from 23 spinal cord injury patients who were all receiving antimicrobial therapy, without any apparent effect on the bladder colonisation. Therefore, a molecular biological approach aimed at restoring the urothelial proliferation to optimum levels appears to be a more natural way of preventing cystitis in spinal cord injury persons. In this context, certain growth factors have been found to be associated with urothelial proliferation. Increased mucosal RNA expression of insulin-like growth factor-II and particularly of type I insulin-like growth factor receptor, as well fibroblast growth factor 1 coincided with re-epithelialisation and urothelial proliferation in mice after acute injury in vivo. ${ }^{8}$ Both high levels of urothelial transforming growth factor beta-1 RNA and protein expression were associated with re-epithelialisation and differentiation after acute injury of mouse urothelium in vivo produced by bladder distension and overstretching which was maintained for 5 min. ${ }^{8}$ The animal study thus shows that urothelial regeneration can be achieved by paracrine or autocrine acting urothelium-derived growth factors. In organotypic mouse urothelial cultures closely mimicking the differentiation and multilayering of normal urothelium, exposure to epidermal growth factor resulted in an increased thickness of 3-5 cell layers, as opposed to 2-3 cell layers in untreated cultures and the cellularity increased from $179 \pm 35$ cells $0.15 \mathrm{~mm}^{-2}$ in untreated cultures to $414 \pm 14$ cells $0.15 \mathrm{~mm}^{-2}$ in epidermal growth factor treated cultures. Rebel and associates demonstrated that epidermal growth factor exposure was associated with an increased number of cell layers and a higher cellular density, as well as a loss of maturation into umbrella cells. ${ }^{9}$ Further investigations focusing on the mRNA expression of insulin-like growth factor-1 receptor and epidermal growth factor receptor mRNA in the urothelium (which can be detected by in situ hybridisation method in formalin-fixed, paraffin-embedded tissue sections $)^{10}$ of the neuropathic bladder of spinal cord injury persons are required so that an appropriate therapeutic strategy may be designed to increase the urothelial proliferation in the neuropathic bladder to the optimum level and, hopefully, reduce the chances of bacterial biofilm formation on the vesical urothelium and subsequent tissue invasion.

Transforming growth factor beta (TGF-B) is a key cytokine that initiates and terminates tissue repair after injury and its sustained production underlies the development of tissue fibrosis. ${ }^{11}$ Neuropathic bladder urothelium is frequently traumatised such as during catheterisation or during bladder distension due to a blocked catheter. After an acute injury to mouse bladder urothelium produced by overdistension, the TGF-B1 RNA expression in urothelial cells was strongly enhanced within $1 \mathrm{~h}$ after the acute injury and an overall high expression of TGF-B1 RNA expression was observed throughout the urothelium at $8 \mathrm{~h}$ after the injury. Thus both high levels of TGF-B1 RNA and protein expression were associated with urothelial re-epithelialisation and differentiation. In addition, TGF-B type-II receptor protein expression was similarly enhanced in the same urothelial cells. As TGF-B1 gene is up-regulated in response to tissue injury, it may be interesting to study the regulation of TGF-B1 secretion, and TGF-B receptor expression in urothelium of neuropathic bladder. In rats, topical or limited intravenous administration of recombinant TGF-B1 normalises wound healing that is impaired by age or glucocorticoids. ${ }^{12}$ In humans, TGF-B2 has been used to repair macular holes. ${ }^{13,14}$ TGF-B therefore has great promise as a therapy for poorly healing wounds. ${ }^{15}$ Further, excessive or sustained production of TGF-B1 is a key molecular mediator of tissue fibrosis. The fibrogenic potential of TGF-B is revealed with repeated injections of higher dose. With recurrent injury, the increase in TGF-B1 production is sustained, leading to the progressive deposition of extracellular matrix and tissue fibrosis. Repeated injury, with continued autoinduction of TGF-B1, overrides the normal termination signals, creating a chronic, vicious circle of TGF-B1 overproduction. The association if any, of possible overproduction of TGF-B and the development of 
small capacity, fibrotic, non-compliant bladder in spinal cord injury persons needs to be investigated. As the complexities of TGF-B regulation in neuropathic bladder are unravelled, a number of therapeutic approaches for modulating its action can be explored which may have enormous clinical potential in spinal cord injury persons.

\section{Acknowledgement}

Our gratitude to Ms Jacqueline Stevens, Regional Spinal Injuries Centre, Southport for the valuable administrative help provided for carrying out this study.

\section{References}

1 Weitzman SA, Weitberg AB, Clark EP, Stossel TP. Phagocytes as carcinogens: malignant transformation produced by human neutrophils. Science 1985; 227: 1231-1233.

2 Case records of the Massachusetts General Hospital, case 31-1993. N Engl J Med 1993; 329: 417-423.

$3 \mathrm{Jie}$ L. Study on infectious mechanism of type 1 fimbriated Escherichia coli in experimental cystitis in mice. Chong-Kuo-IHsueh-Ko-Hsueh-Yuan-Hsueh-Pao 1993; 15: 250-254.

4 Boon ME, Howard CV, van Velzen D. PCNA independence of Ki-67 expression in HPV infection. Cell Biol Int 1993; 17: 1001-1004.
5 Reid G. Do antibiotics clear bladder infections? J Urol 1994; 152: $865-867$.

6 Reid G et al. Bacterial biofilm formation in the urinary bladder of spinal cord injury patients. Paraplegia 1992; 30: 711.

7 Reid G et al. Bacterial biofilm formation on the bladder epithelium of spinal cord injured patients II. Toxic outcome on cell viability. Paraplegia 1993; 31: 494.

8 de Boer WI, Schuller AGP, Vermey M, Vanderjwast TH. Expression of growth factors and receptors during specific phases in regenerating urothelium after acute injury in vivo. Am J Pathol 1994; 145: 1199-1207.

9 Rebel JM et al. An in vitro model of urothelial regeneration: Effects of growth factors and extracellular matrix proteins. $J$ Pathol 1994; 173: 283-291.

10 Lezzoni JC et al. Rapid colorimetric detection of epidermal growth factor receptor mRNA by in situ hybridization. J Clin Lab Anal 1993; 7: 247-251.

11 Border WA, Noble NA. Transforming growth factor beta in tissue fibrosis. N Engl J Med 1994; 31: 1286-1292.

12 Beck LS et al. One systemic administration of transforming growth factor beta 1 reverses age- or glucocorticoid-impaired wound healing. J Clin Invest 1993; 92: 2841-2849.

13 Smiddy WE et al. Transforming growth factor-beta 2 significantly enhances the ability to flatten the rim of subretinal fluid surrounding macular holes. Preliminary anatomic results of a multicenter prospective randomized study. Retina 1993 13: 296-301.

14 Thompson JT et al. Fluorescein angiographic characteristics of macular holes before and after vitrectomy with transforming growth factor beta-2. Am J Ophthalmol 1994; 117: 291-301.

15 Sporn MB, Roberts AB. A major advance in the use of growth factors to enhance wound healing. J Clin Invest 1993; 92: 2565-2566. 